\title{
THE EFFECT OF MARKETING COMMUNICATION MIX TOWARDS THE PURCHASE DECISION OF MICE PRODUCTS: A CASE STUDY FROM SANTA MONICA HOTEL \& CONVENTION IN BOGOR
}

\author{
${ }^{1}$ Yudhistira Pratama, ${ }^{2}$ Caroline Mutiara Prasandy
}

\begin{abstract}
The MICE industry has been growing in Indonesia. With this potential, the lodgin and accommodation businesses have a bright prospect of growth. Due to this matter, the accommodation industry is facing a tight competition, struggling to stand out from other establishments. Marketing communication mix has been proven to affect consumer's buying behavior and simultaneously consumer's purchase decision. This study investigates the effect of the five elements of marketing communication mix, namely advertising, personal selling, sales promotion, public relation, and direct marketing towards consumer's purchase decision. The study is conducted at Santa Monica Hotel \& Convention Bogor, a convention hotel that focuses on the MICE market. Questionnaires are distributed to 100 organizations that have held MICE activity at the hotel. The data is tested for validity, reliability, normality, heteroscedasticity, and multicollinearity. T-test and F-test is done to test the presence or absence of effect from each marketing communication mix elements towards purchase decision. The result shows that marketing communication mix does have simultaneous effect on purchase decision of MICE products, with personal selling and sales promotion as the elements that affect purchase decision. Advertising, public relation, and direct marketing does not show any effect towards purchase decision.
\end{abstract}

Keywords: Marketing Communication Mix, Purchase Decision, MICE

${ }^{1}$ Corresponding Author, Swiss German University, yudhistira.pratama@lecturer.sgu.ac.id 


\section{Introduction}

Good marketing is essential for success. Individuals and organizations engage in marketing activities both formally and informally (Kotler and Keller, 2012). Kotler and Keller (2012) also stated that finance, operations, accounting, and other business functions will not matter without sufficient products and services demand to make profit. Hence marketing is very important especially in the $21^{\text {st }}$ century. Marketing communication is the art of communicating brands to stand out from others. It outlines the coherent, consistent, and clear use of the company's communication options to send a message to its audiences (Ouwersloot and Duncan, 2008). Its important has grown in recent years, as many products and services are reaching their maturity stage of the life cycle. Thus, it is hard to make a product or service stand out from only the related inherent qualities (Keller, 2001).

According to International Association of Professional Congress Organizers (IAPCO), MICE is a type of tourism where large groups are brought together for a particular purpose and is usually planned in advance. MICE is an abbreviation for meeting, incentive, conference, and exhibition. It encompasses all company activities from casual company outing to formal official meetings (International
Congress and Convention Association, 2017).

Santa Monica Hotel \& Convention is a three stars convention hotel located in Pancawati, Bogor. MICE market has been the focus of Santa Monica for several reasons. Firstly, because of the geographical location of the hotel itself, that statistically has been the top destination for organizations from Jakarta to hold their MICE activities. Secondly, it is because Santa Monica Hotel \& Convention themselves has the vision to become the service provider to cater organizational outdoor activities, such as team building, meeting and company gathering. Santa Monica Hotel \& Convention's vision is "the place for people in tourism industry such as EO, WO, training institution, and other institutions supporting tourism activities such as paintball, rafting, hiking, running, biking, motor sport, off road, mountaineering etc. to gather and bringing the organization towards success".

Santa Monica Hotel \& Convention is aiming on MICE market segment, which usually make purchases under an organization's name. Hence the unit of observation will be organizations that have bought a MICE product and service at Santa Monica Hotel \& Convention. In 
making an effective marketing strategy, deep understanding of the consumer's buying behavior is a must. Therefore, this study will measure the effect of marketing communications mix towards consumer's purchase decision.

Purchase decision is "the buyer's decision about which brand to purchases", means it is the final stage of the buying process that resulted in an action of buying a product or service (Kotler and Armstrong, 2012; in Mustika and Andari, 2015). In purchase decision stage, consumers have already made a preferred brand from the set of alternative brands selection (Gomez and Cuellar-Healey, 2013). It consists of identification of a need or problem, search for information or level of involvement, identification and evaluation of alternatives, and finally purchases decision.

Santa Monica Hotel and Convention has been established since 2000 . With more than 10 years of running business, Santa Monica Hotel \& Convention can be deemed as a good business. It has developed itself into a convention hotel, which cater the needs for organizations activities such as meeting, outbound, gathering, and team outing. However, the significance of marketing communication mix has not been defined in Santa Monica's effort in promotion. Therefore, this study would like to investigate the effect of each marketing communication mix element towards consumer purchase decision of MICE products. For this reason, the research problem is as follows: The effect of advertising, personal selling, sales promotion, public relations, and direct marketing has not been defined by the management of Santa Monica Hotel \& Convention. The research questions for this study are:

1. Does advertising affect purchase decision of MICE products at Santa Monica Hotel \& Convention?

2. Does personal selling affect purchase decision of MICE products at Santa Monica Hotel \& Convention?

3. Does sales promotion affect purchase decision of MICE products at Santa Monica Hotel \& Convention?

4. Does public relation affect purchase decision of MICE products at Santa Monica Hotel \& Convention?

5. Does direct marketing affect purchase decision of MICE products at Santa Monica Hotel \& Convention?

6. Does marketing communication mix affect purchase decision of MICE products at Santa Monica Hotel \& Convention?

\section{Literature Review}

\subsection{Marketing Communication Mix}

The idea of marketing communication mix 
and promotional mix over layering each other, since the uses are pretty similar. Keller (2013) mentions advertising, sales promotion, personal selling, public relation, and direct marketing as forms of communication which are part of marketing communication mix. On the other hand, promotion mix also refers to the types of non-personal and personal communication, which include advertising, sales promotion, personal selling, public relation, and direct marketing (Peter and $\mathrm{J}$, 2007).

\subsection{Advertising}

Advertising is any paid form of nonpersonal presentation and promotion of ideas, goods or services by an identified sponsor which is, the source of the advertising came from the sponsor (Kotler and Armstrong, 2010). Advertising informs customers of a product or service, creating awareness and knowledge about the existence of the product or service (Todorova, 2015). Probably the most common in the marketing real, it is the 'senior' or 'elder statesman' of the marketing communications industry (Pickton and Hartley, 1998). Advertising is delivered through various distribution channels, such as TV, radio, magazines, newspapers and billboards.

\subsection{Personal Selling}

Personal selling is face-to-face interaction with one or more prospective purchasers for the purpose of making presentations, answering questions and procuring orders (Keller, 2013). In personal selling, the seller present ideas and products to the client in personal (Todorova, 2015). Since the 1990s, sellers have a portfolio of relationships with their customers. Maintaining relationship with customer encouraged sales and marketing actions to customers.

\subsection{Sales Promotion}

Sales promotions are short-term incentives to encourage the purchase or sale of a product. Blythe (2006) describes sales promotion as any activity intended to generate a temporary boost in sales. This includes several communications activities pursued in an attempt to provide added value or incentives to consumers, whole sales, retailers, or other organizational customers to stimulate immediate sales (Okyere, Agyapong and Nyarku, 2011).

\subsection{Public relations}

Public relations are variety of programs designed to promote or protect a company's image or it's individual 
product (Keller, 2013). Public relations are not focused on the product and focused at the whole company instead. It creates good publication of the company, in which would influence public opinion about the company (Todorova, 2015). Good image about the company would encourage consumers to buy products from the associated company.

\subsection{Direct Marketing}

Keller (2013) defines direct marketing as use of mail, telephone, fax, email or Internet to communicate directly with or solicit response or dialogue from specific customers and prospects. With the development of technology, direct marketing applies new and attractive forms which contain potential for branding and generating sales, in more than just direct mail or online catalog (Belch and Belch, 2003).

\subsection{Purchase Decision}

Purchase decision is the final stage at which consumer eventually makes a purchase. Purchase intention lies in between evaluation of alternatives and purchase decision and is likely used to study consumer buying behavior towards certain product or service. According to Peter and J (2007), there are 3 types of decision making. It depends on how complex or expensive the product is, and the customer's level of involvement in purchasing the product. The 3 types of decision making are extensive decision making, limited decision making, and routine decision making.

\subsection{MICE}

The word MICE itself is an abbreviation for Meetings, Incentives, Conventions and Exhibitions. MICE sector is a sector of tourism which represents business events and activities, thus the MICE consumers are business traveler and not leisure traveler. According Parkash and Singh (2016), MICE activities a described as follows:

Table 1. MICE activities definition

Source: Parkash \& Singh (2016)

\begin{tabular}{ll}
\hline Meeting & The coming together of a group \\
& of people to discuss or exchange \\
& information. In some regions, \\
& meetings may be seen as a small \\
& scale conference by others. \\
\hline Incentives & Leisure trips emphasizing \\
& pleasure and excitement. \\
\hline Conventions & Event where the primary activity \\
& of the attendees is to attend \\
& educational sessions, \\
& participates in meetings/ \\
& discussions, socialized, or \\
& another organized event. \\
\hline Generally portrayed as \\
presentation of products and \\
services with the object of \\
inducing sale or informing the \\
visitors.
\end{tabular}




\section{Research Method}

This study is a causal research with quantitative method to analyze the data. In conducting a causal research, the intention of the researcher is to be able to state that variable $\mathrm{X}$ causes variable $\mathrm{Y}$. Hence when variable $\mathrm{X}$ is altered, it will make a difference in variable Y (Sekaran, 2003). This study would like to find out how does each dimension of marketing communication mix cause an effect towards purchase decision of the MICE customers. For this study, the unit of analysis is organizations that have previously purchased a MICE product at Santa Monica Hotel and Convention. Hence, the unit of observation for this study is an individual that belong to the buying center of an organization, or the individual that is responsible for the purchase decision making of the organization.

In this study, the population that will be the target of investigation is organizations which has purchased and experienced the MICE facilities of the hotel. Because the unit of analysis is the whole organization, the population of this study is all organizations that have purchased MICE product at Santa Monica Hotel \& Convention in the last 12 months. Sample will be taken from this population, because study of a sample rather than the whole population is "likely to produce more reliable result" (Sekaran and Bougie, 2013). The data is tested for validity, reliability, normality, heteroscedasticity, and multicollinearity. T-test and F-test is done to test the presence or absence of effect from each marketing communication mix elements towards purchase decision.

\section{Result and Discussion}

\section{First Hypothesis}

The first is that advertising will affect the purchase decision. However, the result of the regression shows t-score of advertising is only -2.279 , which is lower than the indicator value in the $t$ table. This result suggests that advertising does not affect the purchase decision. Albeit being the most common form of mass communication, advertising's effect is not significant; if not non-existent; to the purchase decision towards Santa Monica Hotel \& Convention. This gap can be caused by the marketing effort of Santa Monica itself. A form of advertising that have been done by Santa Monica is by placing an advertisement at local magazines, travel magazines, and in Mutiara Biru magazine that is distributed in Blue Bird taxi car. Another reason is because the consumers of MICE products are mainly corporations, which means that the decision made is based on the 
buying center and approach in organizational consumers rely more on relationship marketing, in which personal communication is more effective $(\mathrm{Vu}$, 2016).

\section{Second Hypothesis}

Personal selling is shown to have an effect towards consumer's purchase decision. The t-score is 2.229 , which is relatively higher than the indicator measurement of 1.9876. Personal selling maintains relationship with consumers, which encouraged sales and marketing actions to customers. The success of personal selling might also be coming from the target market itself, which is organizations and not an individual. A business to business market rely more on the personal marketing. $\mathrm{Vu}$ (2016) also stated that personal selling is more powerful than advertising.

\section{Third Hypothesis}

With t-score of 3.343 , sales promotion is the most significant in affecting consumer's purchase decision. Sales promotion is effective because it offers added value or incentives to consumers, whole sales, retailers, or other organizational customers to create immediate sales (Okyere, Agyapong and Nyarku, 2011). Organizations especially companies are always looking for better price offerings, and therefore the promotion and incentives offered by Santa Monica would be appealing to the organizational consumers.

\section{Fourth Hypothesis}

The result of hypothesis testing suggests that public relation is not effective towards purchase decision. This might be caused by Santa Monica's lack of publicity thereof. It is probably also because Santa Monica Hotel \& Convention's has not yet created a strong ground of brand awareness, and because public relation is supposed to market the firm in lieu of its products, it is not effective when applied to establishment like Santa Monica.

\section{Fifth Hypothesis}

The fifth hypothesis stated that direct marketing will have an effect to consumer's purchase decision, which is rejected after hypothesis testing was conducted. Direct marketing's t-score only scored -0.754 while it has to be higher than 1.9876 to be considered have an effect towards purchase decision. Santa Monica Hotel and Convention's direct marketing includes personalized emails sent to each guest, and direct sales call which is often referred to as cold call. The e-mail is sent in an effort to build retention, so it might not affect purchase 
decision in the first place. Cold call can be considered rude when the sales marketer does not call at a convenient time.

\section{Sixth Hypothesis}

Result of the f-test shows that marketing communication mix does affect consumer's purchase decision simultaneously even though some of its elements, namely advertising, public relation, and direct marketing found to have no effect on purchase decision at Santa Monica Hotel \& Convention. The result complies to the theory, as marketing communication is an effort to induce buying behavior towards promoted object, or in this case the purchase decision (Tichindelean, 2015). Careful and precise planning of marketing communication activities will surely lead to higher affectivity of each of the marketing communication mix.

\section{Conclusion}

The aim of this study is to find out does marketing communication mix affect or not affect the purchase decision. Furthermore, the elements of the marketing communication mix area so investigated for their correlation to purchase decision. The investigated elements are advertising, personal selling, sales promotion, public relation and direct marketing. The respondent of this study is MICE consumer, means guests who have held MICE activity at Santa Monica Hotel \& Convention. It is chosen so because Santa Monica itself is a convention hotel, which promotes itself as the place to have MICE activities. The study would like to find out which of the marketing communication mix elements affect MICE consumer's purchase decision.

The data is collected from questionnaire. 100 questionnaires are distributed by email to 100 organizations, based on the guest record. Out of 100 questionnaires, 88 are returned. These questionnaires are then used to be analyzed and several tests were conducted. After the data were tested, the conclusion can be made that marketing communication mix does affect the purchase decision of MICE products at Santa Monica Hotel \& Convention. Some of the elements do affect purchase decision, while some others do not. Based on the affectivity of each element towards purchase decision, the elements can be put in the following order: Sales promotion and personal selling affect purchase decision of MICE products at Santa Monica Hotel \& Convention and is the most effective among the other elements, with t-score of 3.343 and 2.229, which is personal selling less than sales promotion. Direct marketing has t-score of -0.754 , which make it have a very little 
effect on purchase decision of MICE products at Santa Monica Hotel \& Convention. Direct marketing is then considered does not have an effect to purchase decision, since the t-score is below the indicator. Public relation has tscore of -1.182 , which means the effect is even weaker than direct marketing. Hence, public relation too considered does not have an effect to purchase decision of MICE products at Santa Monica Hotel \& Convention. Advertising has t-score of -2.279 , which means it has little to no effect on purchase decision. It is also considered does not have an effect towards purchase decision of MICE products at Santa Monica Hotel and Convention.

The effect of each marketing communication mix elements on purchase decision are highly influenced by the marketing efforts and activities by Santa Monica Hotel \& Convention itself. Where the element is shown to have no effect, it is mainly caused lack of marketing activities that has been executed by Santa Monica's marketing team. Marketing communication mix can be seen to have an effect to consumer's purchase decision. The marketing team at Santa Monica Hotel \& Convention should continue and improve the marketing communication effort to promote its
MICE products more. Especially on personal selling and sales promotion, which have shown to be effective towards purchase decision.

\section{References}

Ainiyah, N., Deliar, A. and Virtriana, R. (2016). The classical assumption test to driving factors of land cover change in the development region of northern part of west Java. International Archives of the Photogrammetry, Remote Sensing and Spatial Information Sciences - ISPRS Archives, 41(July), pp.205-210. DOI: 10.5194/isprsarchives-XLI-B6-2052016.

Badan Pusat Statistik, B. (2018). Industri Besar dan Sedang. Available from: https://www.bps.go.id/subject/9/indust ri-besar-dan-sedang.html.

Belch, G.E. and Belch, M.A. (2003). Advertising and Promotion: An Integrated Marketing Communications Perspective, Learning. The McGrawHills Companies. DOI: 10.1007/s13398-014-0173-7.2.

Berinstein, P. (2003). Business Statistics on the Web: Find Them Fast-At Little or No Cost. New Jersey: Cyber Age Books. 
BPS-Statistics of Bogor City. (2017).

Bogor City in Figures.

Cooper, D.R. and Schindler, P.S. (2014).

Business Research Methods. $12^{\text {th }}$ Ed. New York: Mc-Graw Hill. DOI: 32.710.16.01.

Diskominfo, K.B. (2016). Letak Geografis Pemerintah Kota Bogor. Available from:

https://kotabogor.go.id/index.php/page /detail/9/letak-geografis (Accessed: 11 March 2018).

Drezner, Z., Turel, O. and Zerom, D. (2010). A modified kolmogorovsmirnov test for normality. Communications in Statistics: Simulation and Computation, 39(4), pp.693-704.

DOI: 10.1080/03610911003615816.

Driscoll, D.L. (2011). Introduction to Primary Research: Observations, Surveys, and Interviews, in Lowe, C. and Zemliansky, P. (Ed) Writing Space: Readings on Writing. South Carolina, pp.153-174.

Gomez, M. and Cuellar-Healey, S. (2013). Marketing Module 2: Customer Analysis. Marketing Modules Series, (June).

Hox, J.J. and Boeije, H.R. (2005). Data Collection, Primary vs. Secondary, in
Leonard, K.K. (Ed.). Encyclopedia of Social Measurement. California: Elsevier, pp.593-599.

International Congress and Convention Association, I. (2017). Definition of MICE. Available from: https://www.iccaworld.org/aeps/aeitem .cfm?aeid=29 (Accessed: 11 March 2018).

Johnson, R.A. and Bhattacharyya, G.K. (2001). Statistics Principle and Method. John Wiley \& Sons.

Keller, K.L. (2001). Mastering the Marketing Communications Mix: Micro and Macro Perspectives on Integrated Marketing Communication Programs. Journal of Marketing Management, 17(7-8), pp.819-847. DOI: $10.1362 / 026725701323366836$.

Keller, K.L. (2013). Building strong brands in a modern marketing communications environment. The Evolution of Integrated Marketing Communications: The CustomerDriven Marketplace, 15(July), pp.6582. DOI: $10.4324 / 9781315872728$.

Kotler, P. and Armstrong, G. (2012). Principles of Marketing. New Jersey: Pearson Prentice Hall.

Kotler, P. and Keller, K.L. (2012).

Marketing Management. $14^{\text {th }}$ Ed, 
Prentice Hall. $14^{\text {th }}$ Ed. New Jersey. DOI: $10.1080 / 08911760903022556$.

Latham, B. (2007). Sampling: What is it? Quantitative Research Methods ENGL5377, 1, pp.1-12. DOI: 10.1006/cpac.2000.0439.

Lavrakas, P.J. (2008). Encyclopedia of survey research methods. Thousand Oaks, CA: SAGE Publications.

Lee, D.J.L. (2016). Taiwan MICE Development-from the Benefits of the Combination in MICE and Gaming Industry of Las Vegas Experience. Journal of Tourism and Hospitality Management, 4(1), pp.47-61. DOI: 10.15640/jthm.v4n1a4.

Mahmud, I., Almahirah, M. and Fraihat, S. (2014). The Impact of Promotional Mix Element on Consumer Purchasing Decision. Isra University.

McDaniel, C.J. and Gates, R. (2010). Marketing Research with SPSS. $8^{\text {th }}$ Ed. New Jersey: John Wiley \& Sons.

Mustika, G.A. and Andari, R. (2015). Pengaruh Customer Value Terhadap Keputusan Menggunakan Meeting Package Di Golden Flower Hotel Bandung (Survei Pada Tamu Bisnis di Golden Flower Hotel Bandung), Tourism and Hospitality Essentials (THE) Journal, V(1), pp.869-876.
Okyere, N.Y.D., Agyapong, G.K. and Nyarku, K.M. (2011). The Effect of Marketing Communications on the Sales Performance of Ghana Telecom (Vodafone, Ghana). International Journal of Marketing Studies, 3(4), pp.50-62.

DOI:

10.5539/ijms.v3n4p50.

Ouwersloot, H. and Duncan, T. (2008). Integrated Marketing Communications. New York: McGraw-Hill.

Parkash, R. and Singh, J. (2016). MICE Tourism in India: Challenges and Opportunities. International Journal of Research and Engineering, 03(09).

Pertiwi, N.L.M. (2012). Lima Pilihan Hotel di Bogor. Available from: https://nasional.kompas.com/read/2012 /07/21/08310891/lima.pilihan.hotel.di. bogor (Accessed: 11 March 2018).

Sekaran, U. (2003). Research methods for business. $\quad 4^{\text {th }} \quad$ Ed. $\quad$ DOI: 10.1017/CBO9781107415324.004.

Sekaran, U. and Bougie, R. (2013). Research Methods for Business. $6^{\text {th }}$ Ed. West Sussex: John Wiley \& Sons.

Singh, A. and Masuku, M. (2014). Sampling Techniques \& Determination of Sample Size in Applied Statistics Research: an 
overview. International Journal of

Economics, Commerce and

Management, II(11), pp.1-22.

Available from: http://ijecm.co.uk/wp-

content/uploads/2014/11/21131.pdf.

Tichindelean, M. (2015). The Influence of Marketing Communication on the

Consumer's Buyer Behavior - A Relationship Marketing Approach, Studies in Business and Economics, 10(1), pp.140-145. DOI: 10.1515/sbe2015-0013.

Todorova, G. (2015). Marketing communication mix. Trakia Journal of Science, 13(Suppl.1), pp.368-374. DOI: 10.15547/tjs.2015.s.01.063.

(2016). Units of Analysis and Units of Observation. Open Text books for Hong Kong. Available from: http://www.opentextbooks.org.hk/ditat opic/29184 (Accessed: 22 May 2018).

Weaver, D. and Lawton, L. (2014).

Tourism Management. $5^{\text {th }}$ Ed. Australia: John Wiley \& Sons. 